\title{
MORAL RIGHTS: EXPLORING THE MYTHS, MEANINGS AND MISUNDERSTANDINGS IN AUSTRALIAN COPYRIGHT LAW
}

\author{
Francina CANTATORE AND JANE JOHNSTON ${ }^{* *}$
}

\begin{abstract}
This article examines how moral rights are treated in Australian publishing contracts, and whether this approach is consistent with the expectations of authors, journalists and academics. Although, in theory, moral rights cannot be sold or assigned in Australia, the apparent wide scope for exceptions raises questions of whether there is any real protection afforded to creators under the Copyright Act 1968 (Cth), notably in circumstances that relate to pressure on creators to accept contractual terms in order to get published. Additionally, Australian case law reflects some uncertainty about the traditionally accepted non-economic nature of moral rights. The article examines recent case law in this field, found in Meskenas, Perez and Corby, and considers the literature associated with development of moral rights in Australia. It then presents the findings of a two-part study of moral rights in Australia; first through the results of interviews with 176 Australian authors, journalists and academics, followed by an analysis of 20 publishing contracts. It concludes that - in some, but not all, instances - a combination of the exceptions allowed under the Act and practical exigencies have diluted the unique character of authors' moral rights and have created an environment of uncertainty.
\end{abstract}

\section{INTRODUCTION}

Whilst the Australian Copyright Act 1968 (Cth) ('Copyright Act') protects the moral rights of authors of written work for the duration of their copyright, ${ }^{1}$ it makes provision for authors to consent to derogatory treatment of their work and nonattribution, as well as 'reasonable' infringement. The Copyright Act outlines some of the matters to be taken into account when determining whether treatment of a work was 'reasonable in all of the circumstances'.

\footnotetext{
* BA, LLB(Hons), MA, GDLegPrac, PhD, Assistant Professor, Faculty of Law, Bond University.

** BBus (Communication), MA, PhD, Associate Professor, School of Communication and Arts, University of Queensland.

${ }^{1}$ Copyright Act 1968 (Cth) ss 190, 193, 195AC, 195AI.

${ }^{2}$ Ibid ss 195AR(1), 195AS(1).
} 
Although moral rights cannot be sold or assigned under Australian law, ${ }^{3}$ the scope for exceptions and allowance for consent to derogatory treatment of work, raise the question whether there is sufficient protection for authors under the Copyright Act. This issue is particularly pertinent in circumstances where they may be subject to unreasonable contractual terms in publishing agreements. The question also arises whether there is any substantive difference between waiving moral rights and consenting to their infringement. Arguably, consent could be limited to specific situations or instances, whereas waiver may signify a blanket waiver of the author's rights. However, in some instances where an assignment of copyright occurs, ${ }^{4}$ the omission of any mention of moral rights could be significant, especially where the contract allows for retention of certain rights, with no specific mention of moral rights. In such a case - where there is an assignment of copyright, and in countries where moral rights can be waived - it may be argued that by assigning the copyright and omitting any mention of moral rights, the author is effectively waiving moral rights by implication. These types of provisions create uncertainty for authors, especially in the international context in relation to online publishing. Additionally, there are some instances where publishing contracts effectively ascribe a financial value to moral rights, such as where the author receives financial reward for relinquishing moral rights. ${ }^{5}$ This raises the question: are moral rights truly noneconomic and how do these practices accord with the law and with authors' expectations in relation to their moral rights?

Internationally authors enjoy specific recognition of their moral rights under Article 6bis of the Berne Convention, which provides that an author has a right not only to claim authorship, but also 'to object to any distortion, mutilation or other modification of [a work] or other derogatory action in relation to the said work which would be prejudicial to his honour or reputation'. ${ }^{6}$ The inclusion of moral rights provisions in Australian legislation showed a welcome move towards the Berne Convention's legal recognition of authors' personality rights. ${ }^{7}$ However, despite the inclusion of moral rights in the Copyright Act as a unique 'non-economic right', it is clear that the treatment of moral rights reflects the economic-utilitarian character of the Act itself. ${ }^{8}$

\footnotetext{
${ }^{3}$ Ibid s 195AN(3), which states: ' ... a moral right in respect of a work is not transmissible by assignment, by will, or by devolution by operation of law.'

${ }^{4}$ See, eg, Elsevier, Journal Publishing Agreement $<$ https://www.elsevier.com/_data/ /pdf file/0006/98619/Sample-P-copyright.pdf>.

${ }^{5}$ See discussion below in relation to publishing contracts, in particular: The Media Entertainment and Arts Alliance, Standard Freelance Contributor's Contract $<$ https://writerscontracts.files.wordpress.com/2010/07/alliancemodelcontract20090408.pdf $>$.

${ }^{6}$ Berne Convention for the Protection of Literary and Artistic Works, opened for signature 9 September 1886, 828 UNTS 221 (entered into force 4 May 1896) art 6bis ('Berne Convention').

${ }^{7}$ By way of the 2000 amendments implemented by the Copyright Amendment (Moral Rights) Act 2000 (Cth).

${ }^{8}$ This is also borne out by the decision in Meskenas $v$ ACP Publishing Pty Ltd (2006) 70 IPR 172, discussed below.
} 
Furthermore, authors are constrained in protecting their moral rights because of publishing practices and publishing contract terms.

This article takes a three-part approach to examining this dichotomy. Following an analysis of the literature, including key cases of Meskenas v ACP Publishing Pty Ltd, ${ }^{9}$ Perez $v$ Fernandez ${ }^{10}$ and Corby $v$ Allen \& Unwin Pty Ltd, ${ }^{11}$ it presents empirical research to examine: first, how moral rights are perceived by authors, journalists and academics; and, second, how moral rights are dealt with in Australian publishing contracts and whether publishing practices are, in turn, compatible with the law and in line with authors' expectations. Finally, it considers the complexities and implications of the current treatment of moral rights in publishing in the global environment.

\section{Moral Rights in the Australian Context A Background}

Moral rights were only formally recognised in Australian legislation in 2000, when the Copyright Act was amended - by introduction of the Copyright Amendment (Moral Rights) Act 2000 (Cth) - to incorporate provisions relating to the moral rights of authors. Their introduction followed lengthy debate over many decades, including several government policy inquiries during the 1980s and 1990s. ${ }^{12}$ Rimmer describes the period as 'an epic policy process', typified by political prevarications, convoluted provisions, lobbying and compromise. 13 The decision was ultimately seen by some as a government capitulation, with the admission that existing laws were 'fragmentary and incomplete'; not able to be accommodated by existing laws of defamation and passing off. ${ }^{14}$

The Copyright Amendment (Moral Rights) Act 2000 (Cth) protects the 'moral right' of authors as a right of attribution of authorship; or a right not to have authorship

\footnotetext{
${ }^{9}$ (2006) 70 IPR 172.

${ }^{10}$ (2012) 260 FLR 1.

${ }^{11}$ (2013) 297 ALR 761.

${ }^{12}$ Matthew Rimmer, 'Moral Rights and Their Application in Australia' (2004) 15 Federal Law Review $331<$ http://www.austlii.edu.au/au/journals/FedLRev/2004/15.html\#fn3>; see also Attorney-General's Department Copyright Law Review Committee, Report on Moral Rights (1988); Attorney-General's Department, Proposed Moral Rights Legislation for Copyright Creators (1994); Senate Legal and Constitutional Legislation Committee, Commonwealth Parliament, Copyright Amendment Bill 1997 (1997) (concerning the Bill that became the Copyright Amendment Act (No 1) 1997 (Cth).

${ }^{13}$ For further discussion see Matthew Rimmer, 'Shine: Copyright Law and Film' (2001) 12 Australian Intellectual Property Journal 129; Matthew Rimmer, 'Crystal Palaces: Copyright Law and Public Architecture' (2002) 14 Bond Law Review 320.

${ }^{14}$ Leanne Wiseman, 'Moral Rights in the Australian Academy: Where to Now?' (2005) 28(1) UNSW Law Journal 98.
} 
falsely attributed; or a right of integrity of authorship. ${ }^{15}$ In the case of Perez, ${ }^{16}$ outlined below, Federal Court Magistrate Driver FM advocated for the independent existence of moral rights from the bundle of 'economic' rights protected by copyright. He outlined how they were inalienable to the author, giving protection to the investment of the author's personality in his or her creation, drawing jurisprudential force from civil law traditions and international copyright and human rights conventions to which Australia is a party. He cited the (then) Attorney-General's Second Reading Speech in introducing the relevant amendments to the Copyright Act in 1999:

... this bill is not just about fulfilling international obligations. More importantly, it is about acknowledging the great importance of respect for the integrity of creative endeavour. At its most basic, this bill is a recognition of the importance to Australian culture of literary, artistic, musical and dramatic works and of those who create them. $^{17}$

Thus, the inclusion of Part IX in the Copyright Act, dealing exclusively with moral rights, signified the legal recognition of Australian authors' personality rights and reflected the philosophies of $19^{\text {th }}$ and $20^{\text {th }}$ century theorists. ${ }^{18}$ Its aim was, however, not only to protect the personality of authors, but also to provide incentives for creators to continue to create for the public benefit. It was evident that, historically, the recognition of moral rights in Australia was closely connected to economic incentives. ${ }^{19}$ Notionally, moral rights provisions protect the creator rather than the copyright holder. However, as previously pointed out by Adeney, ${ }^{20}$ the Australian system may be regarded as 'a hybrid system with authorial moral rights grafted onto a framework that has developed to protect the economic interests, not of the author, but the copyright owner'. This approach was also taken in the earlier Australian Ergas Committee Report, which stated that 'the general objective of the system of intellectual property law in Australia is utilitarian, and more specifically economic, rather than moral in character'. ${ }^{21}$ Further:

... the Australian tradition in intellectual property law is more explicitly utilitarian: in the sense of seeking to maximize social welfare, rather than focusing on IP as having intrinsic value and hence merit. ${ }^{22}$

\footnotetext{
${ }^{15}$ Copyright Act $\mathrm{s} 189$.

${ }^{16}$ Perez v Fernandez (2012) 260 FLR 1.

${ }^{17}$ Ibid 15.

${ }^{18}$ See, eg, Justin Hughes, 'The Philosophy of Intellectual Property' (1988) 77 Georgetown Law Journal 330.

${ }^{19}$ Intellectual Property and Competition Review Committee, Parliament of Australia, Review of Intellectual Property Legislation under the Competition Principles Agreement (2000) 33 ('Ergas Committee Report').

${ }^{20}$ Elizabeth Adeney, 'Moral Rights and Substantiality' (2002) 13(1) Australian Intellectual Property Journal 5, 10.

${ }^{21}$ Ergas Committee Report, above n 19, 33.

${ }^{22}$ Ibid 43.
} 
According to Stokes, moral rights could be justified on economic and public policy grounds for the following reasons: consumer interest was served by establishing the authenticity of products and, further, the value of a product would be increased if it was shown to be original. ${ }^{23}$ Whilst particularly true in the field of art, this line of reasoning is applicable to all forms of creative endeavour, especially when viewed within the ambits of transformative capabilities. This also applies in academic writing, where, although there is generally no direct financial reward for authors, the value of writing and research is closely linked with the persona of the author.

Most of the literature on moral rights has examined the concept from an international perspective ${ }^{24}$ or within a specific context, such as the digital treatment of moral rights. ${ }^{25}$ This article provides a new examination by bringing together case law, the perceptions of those using the law and the writing contracts that may or may not employ elements of the law.

\section{B Current Law}

As noted, under s 195AWA of the Copyright Act, there is no infringement of an author's moral rights if the author has consented in writing to any acts or omissions relating to these rights, or if the infringement was 'reasonable'. Such rights include the right to have the work attributed to the author, not to treat it in a derogatory manner, including not changing the work without the author's consent. ${ }^{26}$

International scholars have noted a distinction between economic and personal rights as being either dualist or monist. The dualist perspective justifies the unequal treatment of moral and economic privileges as corresponding to two different legal objectives: (a) the protection of the author as an individual by means of his work; and (b) the provision of economic profit for the author. In contrast, monist systems give similar priority to both rights based on the inseparable character of the elements coinciding in copyright. ${ }^{27}$ Accordingly, dualist countries (including France, Belgium, Brazil, Greece, Italy, Mexico, Portugal, and Spain) hold that moral rights are inalienable, cannot be waived and may be considered perpetual, while the economic privileges are limited in time. Monist countries (including Germany, Argentina, Austria, Finland, the Netherlands, Norway, Sweden, and Switzerland) consider moral

\footnotetext{
${ }^{23}$ Simon Stokes, Art and Copyright (Hart Publishing, $1^{\text {st }}$ ed, 2001) 65.

${ }^{24}$ See, eg, Gerald Dworkin, 'The Moral Right of the Author: Moral Rights and the Common Law Countries' (1994) 19 Columbia-VLA Journal of Law and Arts 229; Adeney, above n 20 .

${ }^{25}$ See, eg, Baseem M Melhem, Marah Maidi Al-Abweh and Haitham A Haloush, 'ReConceptualising Moral Rights in the Digital Era' (2008) 72 Intellectual Property Forum 44; J Carlos Fernandez-Molina and Eduardo Peis, 'The Moral Rights of Authors in the Age of Digital Information' (2001) 52(2) Journal of the American Society for Information Science and Technology 109.

${ }^{26}$ Copyright Act ss 195AR(1), 195AS(1).

${ }^{27}$ Fernandez-Molina and Peis, above n 25, 112-13.
} 
rights to be as long-lived as economic rights, and like economic rights, they too can be waived. ${ }^{28}$

Most common law countries have adopted an approach that makes moral rights inalienable but waivable. ${ }^{29}$ Dworkin's analysis of moral rights in common law countries, published several years prior to their introduction in Australia, ${ }^{30}$ and focusing closely on the United Kingdom ('UK'), concluded that exceptions and qualifications to moral rights in the UK could be seen to 'modify, some would say emasculate, moral rights in the light of business reality'. ${ }^{31}$ Others argued that this balance, which favours business over individual personal rights, undermined the essence of moral rights. ${ }^{32}$ As such, the adoption of moral rights in the UK has been described as 'cynical', 'half-hearted' and 'lacking conviction', attributed to legislators being 'primarily concerned to preserve the interests of exploiter groups against moral rights encroachments, rather than to recognise and enforce authors' interests. The resulting legislation reflects that ambivalence'. ${ }^{33}$

Meanwhile, the digital environment, which has altered information processing, publishing and transmission globally, has added significant complications to moral rights of authors. Fernandez-Molina and Peis note how:

agreement on appropriate legislation for the protection of authors' moral rights in the context of the current international scenario, then, means resolving three separate conflicts: (1) authors versus publishers, (2) authors versus users, and (3) droit d'auteur versus copyright. ${ }^{34}$

While representing separate conflicts, these conflicts also overlap, notably in the Australian context, which has seen only a handful of moral rights cases to date. Three cases have tested moral rights in Australia since their introduction into the Copyright Act in 2000. In each case, a separate element of moral rights was tested: false attribution in Meskenas; integrity and degradation of work in Perez; and attribution in Corby. Notably, in Meskenas and Perez, the Court took very different positions on the relationship between moral rights and economic rights, as outlined below.

\footnotetext{
${ }^{28}$ Ibid.

${ }^{29}$ Deming Liu, 'The Artist Has Got Moral Rights and That Ain't Bad' (2011) 33(3)

European Intellectual Property Review 169, 175.

${ }^{30}$ Dworkin, above $\mathrm{n} 24$.

${ }^{31}$ Ibid 256.

${ }^{32}$ Liu, above n 29, 175.

${ }^{33}$ Ibid.

${ }^{34}$ Fernandez-Molina and Peis, above n 25, 114.
} 


\section{Meskenas v ACP Publishing Pty Ltd}

Australia's first case of moral rights found an artist successfully suing the publisher of Woman's Day magazine for infringing his rights of attribution. ${ }^{35}$ Of note, the case also confirmed the Court's connection between economic and moral rights. This was the first time an Australian court had considered the financial value of moral rights. ${ }^{36}$ The case, which considered whether copyright and moral rights had been infringed in attributing a painting to the wrong artist, found copyright had not been infringed because the artist did not own the painting's copyright but his moral rights had been infringed. In deciding the case, Magistrate Raphael opined: 'I am of the view that the respondent cannot escape liability for its actions in infringing the moral right of the applicant not to falsely attribute the authorship of the painting on the ground submitted. ${ }^{37}$ In determining damages he noted the lack of authority on which to determine quantum, reverting to an economic loss equivalency: 'In my view the primary damages for the infringement of moral rights in this case should reflect those which I would have awarded if I had believed that there was an infringement of the applicant's copyright. ${ }^{38}$

While the award of $\$ 1,100$ was based on wrongful attribution, Magistrate Raphael awarded a further $\$ 8,000$ to $\mathrm{Mr}$ Meskenas for aggravated damages, based on the conduct of the publisher in refusing to publish an apology despite repeated requests. ${ }^{39}$ Because there was no commercial dealing, the moral rights breach was equated to a breach of copyright. ${ }^{40}$ One commentator noted: 'It is not clear whether this is a universal principle, or whether different considerations apply in assessing these damages where there has been a commercial dealing., ${ }^{41}$

\section{Perez v Fernandez}

In contrast to Meskenas, this case was the first to consider the integrity of authorship and the right not to have work subjected to derogatory treatment. ${ }^{42}$ At issue were the moral rights and copyright infringement of internationally known rap/hip-hop artist Armando Perez, known as 'Pitbull', by Perth disk jockey and music promoter Jaime Fernandez. The case centred on how Fernandez had combined an 'audio drop' he had received from Perez with the words from Perez's song 'Bon Bon', uploaded the

\footnotetext{
${ }^{35}$ Meskenas $v$ ACP Publishing Pty Ltd (2006) 70 IPR 172. In this case, a photograph of Princess Mary of Denmark standing in front of a portrait of the late heart surgeon Victor Chang, which had been painted by Mr Meskenas, was falsely attributed to another artist, Jiawai Shen, when published in Woman's Day magazine.

${ }^{36}$ Michael Napthali, A Picture Tells a Thousand Dollars (2 August 2007) Communications Council <www.communicationscouncil.org.au/public/content/ViewCategory.aspx?id=748>.

${ }^{37}$ Meskenas v ACP Publishing Pty Ltd (2006) 70 IPR 172, 187.

${ }^{38}$ Ibid 189.

${ }^{39}$ Ibid 190.

${ }^{40}$ Napthali, above n 36 .

${ }^{41}$ Ibid.

${ }^{42}$ Perez v Fernandez (2012) 260 FLR 1.
} 
altered 'Bon Bon' song to his website, streamed it and played it at nightclubs. Perez, as the author of 'Bon Bon', and two companies who owned the copyright in the sound recording of the song, brought an action against Fernandez in the Australian Federal Magistrates Court seeking damages and other remedies. ${ }^{43}$

In his judgment of the case, Driver FM separated the moral rights from the copyright, citing Meskenas:

In Meskenas, the Court ultimately took the view that the compensation awarded for moral rights infringement should reflect that which it would have awarded for copyright infringement. The applications submit that this approach would not be apposite here. In this case there are two distinct groups of applicants involved: $\mathrm{Mr}$ Perez sues on the basis of his moral rights; the second and third applications sue on the basis of their copyright. Were the conflation of copyright and moral rights damages in Meskenas to be applied here without appreciation of the underlying factual differences it would leave one class of applicant uncompensated at the expense of the other. ${ }^{44}$

Driver FM said, however, he did not accept that Mr Perez had suffered any lasting damage and while his moral rights had been infringed, causing distress, an apology had been made by Fernandez, albeit grudgingly so. He awarded Perez \$10,000 for the moral rights infringement. ${ }^{45}$ Compensatory damages to the copyright owners were considerably lower at $\$ 2,312$ each, thus representing not only Australia's first case which purposefully separated moral and economic rights, but in so doing, awarded a higher compensation for moral rights than for the copyright breach.

\section{E Corby $v$ Allen \& Unwin}

Corby ${ }^{46}$ further extended the moral rights law findings in Meskenas and Perez. The dispute centred on the use of photographs in Eamonn Duff's book the Sins of the Father, published by Allen \& Unwin. Members of the Corby family claimed copyright in five of the 37 photographs in the book had been infringed by Allen \& Unwin, and that the moral right of attribution had been infringed in four of the photographs. Buchanan $J$ found that the lack of attribution did not follow industry practice, as asserted by Allen \& Unwin, and, in any case, the publisher had identified other photographers throughout the book. Buchanan $\mathrm{J}$ found the publisher had infringed the moral rights by non-attribution. In ordering damages for copyright infringement totalling almost $\$ 55,000$, he noted that the 'infringement of copyright must be taken into account in assessing damages for moral infringement' ${ }^{47}$ It is also worth noting that Buchanan J said he was not satisfied that any of the applicants had:

\footnotetext{
${ }^{43}$ Melanie Bouton, Damages Awarded for Moral Rights Infringement (9 March 2012) Freehills <www.herbertsmithfreehills.com/-/media/Freehills/A09031221\%2025.PDF>.

${ }^{44}$ Perez v Fernandez (2012) 260 FLR 1, 16-7.

${ }^{45}$ Ibid 19.

${ }^{46}$ Corby v Allen \& Unwin Pty Ltd (2013) 297 ALR 761.

${ }^{47}$ Ibid 783.
} 
suffered a loss resulting from lack of attribution, whether loss includes commercial loss or injury to feelings. There is no reason to conclude that any of the applicants would have wished their name to be published in connection with a photograph of which they were the author. ${ }^{48}$

He added:

I am prepared to make a declaration that the moral rights of attribution of each of the applicants has been infringed in the present case, even though the infringement seems to me to be more a question of form than substance. ${ }^{49}$

Thus, whilst drawing a distinction between copyright and moral rights, he appeared to give precedence to copyright infringement over that of moral rights in assessing damages, finding no evidence of financial loss in relation to moral rights.

It is interesting that these three cases each tested separate aspects of the moral rights provisions: Meskenas tested the right not to have work falsely attributed; Perez examined the right to maintain the integrity of a work; and Corby saw to the right of attribution. It is also worth noting that the two most recent cases (Perez in 2012 and Corby in 2013) both occurred after the following study in 2010 which sought to investigate the perceptions and knowledge of authors, journalists and academics (who also worked in the field of writing) in relation to moral rights. Thus, it is important to remember as we examine the findings below that, with the exception of Meskenas (which dealt with artists' rather than authors' moral rights), respondents did not have the Australian case law to base conclusions on and were largely drawing from either a theoretical knowledge of the field of moral rights, international case law, or international experience.

\section{MORAL RightS UNDER SCRUtinY: Authors, JOURNALISTS AND ACADEMICS}

The article now moves to the empirical findings - drawn from interviews, a survey, and a content analysis - in an attempt to gain insights and a deeper understanding of the way moral rights are both perceived by users and incorporated into Australian publishing contracts. Findings from the interviews and survey of 176 Australian authors, academics and journalists (collectively referred to as 'authors') are examined first, followed by the results of the content analysis of 20 publishing contracts and guidelines from various sources. These collective results are, to the best of our knowledge, the first empirical findings about perceptions of moral rights and their implementation into contracts since they were introduced in Australia in 2000.

\footnotetext{
${ }^{48}$ Ibid.

${ }^{49}$ Ibid.
} 


\section{A Methodology}

The empirical study employed a triangulated approach, using qualitative and quantitative methods over a multi-phased time-frame. It was conducted during between 2010 and 2011, involving survey data obtained from a total of 176 authors, journalists and academics, using a combination of in-depth personal interviews undertaken face to face in Brisbane, Sydney, Melbourne and the Gold Coast ${ }^{50}$ and a survey, administered via Survey Monkey, to members of the Australian Society of Authors. Participants in the research were selected by way of of 'purposeful sampling', as described by Patton. ${ }^{51}$ Therefore, many of the participants were categorised as "elite interviewees" ${ }^{52}$ due to their leading and often influential roles within the Australian writing community. Interview responses included first-hand examples of how moral rights had affected them while the survey group provided a broader range of more generalised perceptions, based on the larger number of respondents.

This phase of the research aimed to determine whether the views of Australian authors reflected an acknowledgement of the utilitarian objectives of Australian copyright law (including moral rights), and whether they regarded moral rights as separate from copyright. It was also intended to determine what the level of understanding and knowledge about moral rights was amongst the participants. These findings were then used as a foundation for examining a sample of Australian publishing contracts, to ascertain if such contracts reflected authors' understanding of moral rights. A total of 20 Australian publishing contracts were examined, including journals, book publications and journalism contracts, to ascertain how moral rights are treated in practice, and whether their treatment is consistent with authors' expectations and the law. These contracts were located via internet searches, between 2013 and 2015.

\section{B The Meaning and Value of Moral Rights}

Participants in the survey and face-to-face interviews were asked specific questions relating to their understanding of moral rights. First, what do moral rights mean to them as creators; and, second, did they feel that their moral rights were sufficiently protected under the Australian copyright structures?

In the online survey, approximately 95 per cent of the 156 participants indicated that they viewed moral rights as important and approximately 63 per cent of these

\footnotetext{
${ }^{50}$ Francina Cantatore, Negotiating a Changing Landscape: Authors, Copyright and the Digital Evolution (PhD Thesis, Bond University, 2011) 131. For a full discussion of the methodology employed see 130-44.

${ }^{51}$ Michael Patton, Qualitative Evaluation and Research Methods (Sage Publications, 1990)

169. See also R E Stake, 'Qualitative Case Studies' in Norman K Denzin and Yvonna Lincoln (eds), Handbook of Qualitative Research (Sage Publications, $3^{\text {rd }}$ ed, 2005) 451.

${ }^{52}$ Catherine Marshall and Gretchen B Rossman, Designing Qualitative Research (Sage Publications, $3^{\text {rd }}$ ed, 1999).
} 
respondents stated that it was 'very important'. ${ }^{53}$ Not a single respondent viewed moral rights as 'unimportant' or 'not important at all'. ${ }^{54}$ Thus it appeared that most of the respondents were strongly aware of the importance of moral rights.

On the question of whether they thought their moral rights were sufficiently protected under the current copyright structure, the respondents appeared to be doubtful. Only approximately 30 per cent of participants agreed with the proposition ' $M y$ moral rights are adequately protected under the current structure', with over 40 per cent stating that they were undecided. ${ }^{55}$ Almost a third of participants disagreed that their moral rights were adequately protected. This result reflected an uncertainty in the sample group regarding the adequacy of protection of their moral rights afforded by the current copyright legislation and government structures. Moreover, although participants expressed an overwhelming bias in favour of the importance of moral rights, there appeared to be a substantial lack of knowledge about the level of protection afforded to them by current structures in respect of their moral rights. ${ }^{56}$

The responses by interviewees varied from indifference to strong appreciation of moral rights, with some participants acknowledging the value of moral rights, not only as a concept reflecting personality rights but also as a specific right which resulted in an economic benefit. Although most of the interviewees were aware of the inclusion of moral rights in the legislation, one author admitted that he had no idea what moral rights were and another saw it as 'just another form of copyright'. 57

Most authors recognised that moral rights gave authors the right to be identified as the creator of the work and to be able to determine how their work should be treated. One author, who was also a publisher, stated that it meant that 'creators' rights go beyond a fiscal matter and that they have a genuine say in how their work is treated'. ${ }^{8}$ An academic participant emphasised the importance of the right to be identified as the author, especially where writing had been commissioned for a flat fee and then made available online as a value-adding tool by the publisher, with no further payments (to the author) attached to the writing. ${ }^{59}$ This view was echoed by another participant who stated further: 'Moral rights mean a great deal to me. It is my right for my created works to be acknowledged as mine. 60

A bestselling non-fiction author and academic proposed quite an extensive protection scheme, extending beyond the original work:

\footnotetext{
${ }^{53}$ Cantatore, above n 50, 159.

${ }_{55}^{54}$ Ibid.

${ }^{55}$ Ibid $159-160$.

${ }^{56}$ Ibid 159.

${ }^{57}$ Ibid 161.

${ }^{58}$ Ibid 160.

${ }^{59}$ Ibid.

${ }^{60}$ Ibid.
} 
As a professional author, I require the moral right to assert or disclaim my authorship over a work, and to object to any editing changes which may undermine my reputation. In my experience, this also extends to the meta-documents and metaprocesses which support the work, such as press releases, interview quotations, and even the types of third party companies which are permitted to use my books (or extracts therefrom) as promotional for their own products or services. ${ }^{61}$

This viewpoint reflected the acknowledgement that moral rights not only entitled the author to assert authorship rights, but also to determine how the material was treated by external parties. It further recognised that without this right an author would lose the ability to control how his or her work was used.

A bestselling fiction author regarded the value of moral rights as a tangible right to be asserted or alienated by the author at will. He described the meaning of moral rights to him as a creator as follows:

It means that I can make some claims as to the integrity of the work, that people can't come along and change my work and have my name attached to it, and make it something that is drastically dissimilar to the book that I had written in the first place. In a way, that changes its meaning or changes what I wanted to achieve by writing it. I think that it's good that there is some notion paid to the integrity of the work that honours the intention of the author who created it. ${ }^{62}$

He went on to elucidate by using the example of his book where international film rights were sold to an Italian filmmaker:
When you sign off your film rights you have to sign away any moral rights over the film ... because in buying your film rights they reserve the right to do whatever they want with it in order to get it made. And they will change the characters and they will change the story and I'd much rather that was spelled out up front. I think they probably feel that in order to be able to make a film without that impediment, they need to know you're not going to take action against them, saying, 'but that's not what my story was like'. ${ }^{3}$

This author pointed out that, in that case, the producer not only changed the name of the characters and the name of the book, but the setting was changed from an Australian city in mid-summer to mid-winter in Italy's north. He was not unhappy with the changes and had willingly relinquished his moral rights, observing: 'There were times when I was thinking, why did you even pay me at all? But I was happy to take it. I accept that and I think it's kind of good that contracts require that to be spelled out so that you know what you're up for ... I've even signed contracts that have had specific clauses saying that I have no right to complain publicly if I don't like the end result.' His comments, based on his own experience, illustrated the economic value that authors may attach to their moral rights when contemplating the

\footnotetext{
${ }^{61}$ Ibid.

${ }^{62}$ Ibid 161.

${ }^{63}$ Ibid.
} 
overseas assignment of their copyright, especially film rights, and the consequences of the alienation of such rights. In the context of this research this author was viewed as an 'elite interviewee', more aware of and concerned with moral rights, due to the wide distribution of his work and his first-hand involvement with moral rights in his contracts. $^{64}$

Some participants raised concerns about moral rights, for example: 'My USA publisher changed the wording of one of my books without my permission'. ${ }^{65}$ This 'Americanisation' of the language impacted on the Australian 'flavour' and culture represented in his writing. Whilst most respondents stated that it was impossible to protect their copyright online, very few favoured flexible licensing models such as the Creative Commons. ${ }^{66}$

Only a small group of writers, who could be described as 'industry experts' by virtue of their extensive knowledge of publishing, had what might be considered a full, working knowledge of the scope of moral rights protection in Australia. They understood that moral rights not only entitled the author to assert authorship rights, but also to determine how the material is treated by external parties. On a philosophical level, their comments echoed Barthes' viewpoint, ${ }^{67}$ which suggests that an author only remains the author for the time he maintains control over the work.

What emerged from the research were inconsistencies in the ways authors, journalists and academics generally viewed moral rights. Though most appreciated the 'personality rights' aspect of moral rights, some associated moral rights with economic benefits. Most concerning, however, was the lack of confidence and knowledge regarding moral rights protection under Australian law. It was evident that the effectiveness of Australian moral rights protections in practice merited further investigation.

\section{Publishing Contracts and Moral Rights}

In the context of the literature and the research conducted above, the second part of the study examined how moral rights provisions are implemented in Australian publishing contracts. Further, how the treatment of moral rights in publishing contracts impact on authors, journalists and academics. As noted earlier, a sample of 20 publishing contracts and publishing guidelines was taken from well-known Australian academic journals, magazine publishers and book publishers. The sample represents a 'purposive sample' of academic journal contracts published by universities and major publishers, a commercial publisher, and magazine and newspaper publishers. The findings are discussed below as they relate to relevant clauses dealing with copyright and moral rights provisions. In assembling the sample

\footnotetext{
${ }^{64}$ Ibid $161-2$.

${ }^{65}$ Ibid 186.

${ }^{66}$ Ibid 238. Creative Commons recognises the author's moral rights and provides licensing options pursuant to the provisions of the Copyright Act $\mathrm{s} 189$.

${ }^{67}$ Roland Barthes, The Death of the Author (1977) 142.
} 
access was obtained to online agreements and in this regard convenience was a factor in the methodology. ${ }^{68}$

Of interest is the diversity of clauses and inconsistency with which moral rights are treated by different publications. Although some publications specifically recognise the author's moral rights, others do not mention moral rights at all, and a further group require the author to consent to infringement of moral rights. There are also inconsistencies in the ways journals published by the same publisher treat moral rights. For example, the two Thomson Reuters journals cited as examples, the Australian Law Journal ('ALJ') and Australian Intellectual Property Journal ('AIPJ'), deal with moral rights in different ways. The ALJ makes no mention of moral rights whilst the AIPJ recognises the author's moral rights and both apply a wide discretion in favour of the publisher to modify the author's work. ${ }^{69}$ Additionally, inconsistencies in the wording of the AIPJ clauses could create confusion for authors as to the scope of their consent to infringement of their moral rights, in view of a provision giving the publisher 'absolute discretion' to deal with the article. ${ }^{70}$ In the case of the ALJ, there is no reference to moral rights, and in addition there is provision for the assignment of 'all rights under the agreement' to the publisher. ${ }^{71}$ As the 'absolute discretion' of the publisher again extends to modifications of the work, it may be understood that the publisher is asserting the ability to assign any moral rights related consent it may have under the agreement. Because moral rights are not specifically mentioned in this agreement, this assignment clause could potentially impact on the Copyright Act provision dealing with non-assignability of moral rights under the Act. ${ }^{72}$ Although the publisher may argue that the legislation does not prohibit the assignment of rights under the licence, but rather the moral rights themselves, to take such a view would militate against the spirit of the protection afforded to the author under the Act. The non-assignment proviso has not been tested in our courts to date, but the lack of clarity in these contract provisions can only lead to confusion and uncertainty for authors.

Some agreements, although used in Australia for Australian authors, emanate from international publishers. An agreement from publisher Elsevier provides that authors assign copyright in their manuscript to the publisher throughout the world, for the full term of the copyright. It makes no mention of authors' moral rights. Presumably these moral rights will not be part of the assignment in the Australian context, but given the diversity of ways in which moral rights are treated globally, it is unclear what the publisher envisaged with this clause, and whether they may perceive moral rights to

\footnotetext{
${ }^{68}$ Patton, above n 51, 182.

${ }^{69}$ AIPJ, Submission Requirements, Thomson Reuters < sites.thomsonreuters.com.au/ journals/files/2015/10/AIPJ.pdf>; ALJ, Submission Requirements, Thomson Reuters $<$ sites.thomsonreuters.com.au/journals/files/2015/11/ALJ-Submission-requirements.pdf $>$. ${ }^{70}$ AIPJ, above n 69.

${ }^{71}$ ALJ, above n 69.

${ }^{72}$ Copyright Act s 195AN: ‘... a moral right in respect of a work is not transmissible by assignment, by will, or by devolution by operation of law.'
} 
be a part of the bargain. From a practical perspective, if the publisher infringes authors' moral rights, it could be difficult for Australian authors to address extraterritorial infringements of their rights, not only from a contractual perspective, but also due to the reciprocal protection provisions under the Berne Convention and the fact that, for example, in the US moral rights are not afforded to literary authors.

Previously, similar problems could arise in Taylor \& Francis (Routledge) agreements, which also have international scope. Although used in Australia, their previous agreement referred to the Copyright, Designs and Patents Act 1988 (UK) when acknowledging the author's moral rights. That agreement gave the publisher 'absolute discretion' to modify and adapt the work and provided for assignment of the copyright to the publisher. However, over the last year Taylor \& Francis have updated its copyright provisions and currently an author has the option to either assign copyright to it or elect to retain copyright and grant it an exclusive licence to publish the work for the full term of the copyright. No specific mention is made of moral rights. ${ }^{73}$

The University of New South Wales Law Journal ('UNSW Law Journal') contract also makes provision for 'assignment of copyright in the work to the Journal once it has been formally accepted for publication. This entitles the Journal, amongst other things, to publish the submission in any format and allow third parties to do so on such terms as the Editor thinks fit'. ${ }^{74}$ The Melbourne University Law Review contract has similar provisions relating to copyright and requires assignment of copyright with no specific mention of moral rights, ${ }^{75}$ although it states that 'the Editors normally consult the author (or authors) before making any major changes', which appears to acknowledge the author's moral rights. However, the use of the word 'normally' raises the possibility that major changes could be effected to the work without the author's knowledge, implying a broad consent to change the work. This may fall within the scope of the legislative provisions as long as the work is not treated in a derogatory manner. ${ }^{76}$ The Monash University Law Review also requires all authors to assign the copyright in their work to Monash University, and makes no mention of moral rights on its website. ${ }^{77}$

In a different approach, copyright of articles published in the University of Queensland Law Journal ('UQLJ') is vested jointly in the UQLJ and the

\footnotetext{
${ }^{73}$ See $<$ http://authorservices.taylorandfrancis.com/copyright-and-you/ $>$; $<$ http://author services.taylor andfrancis.com/wp-content/uploads/2015/07/licence-to-publish.pdf $>$.

${ }^{74}$ See UNSW Law Journal, Author Agreement $<$ www.unswlawjournal.unsw.edu.au /sites/default/ files/unswlj_author_agreement_2.pdf $>$.

${ }^{75}$ See Melbourne University Law Review, Publication Policy, <http://law.unimelb. edu.au/_data/assets/word_doc/0008/1586141/2014PublicationPolicy1.doc $>$.

${ }^{76}$ Copyright Act s 195AWA.

${ }^{77}$ See Monash University Law Review, Submitting an Article, <www.monash.edu /law/about-us/publications/monlr/submissions $>$.
} 
contributor. ${ }^{78}$ The Sydney Law Review similarly states on its website that "copyright in articles published in the Sydney Law Review is vested in the Sydney Law Review and its contributors'. ${ }^{79}$ In both cases, no mention is made of moral rights under their guidelines, which may create uncertainty for authors as to how their moral rights will be treated. No sample agreements for these two journals were publicly available at the time of this article.

Only eight of the journals and publishers examined provide for retention of copyright by the author, which is then subject to a variety of permissions. For example, the Queensland University of Technology Law Review ('QUT Law Review') provides for retention of copyright by the author, subject to the journal having right of first publication, with the work simultaneously licensed under a Creative Commons Attribution Licence that allows others to share the work with an acknowledgement of the work's authorship and initial publication in the QUT Law Review. ${ }^{80}$ The Australian Indigenous Law Review and University of Tasmania Law Review similarly allow for retention of copyright, subject to a non-exclusive licence to publish the article, the latter also providing for publication by third parties. ${ }^{81}$ These approaches align with the Social Sciences Research Network ('SSRN') copyright provisions that allow for retention of copyright by the author and a non-exclusive, revocable licence to the publisher. ${ }^{82}$ The University of Western Australia Law Review briefly states on its website that copyright remains with the individual authors. ${ }^{83}$ Notably, none of these publications make a direct reference to moral rights. Most provide for the ability to adapt and modify the format of the work as necessary for publication; however, these modifications would be grammatical or typographical rather than substantive.

It is interesting to note how the licence provisions vary as between journals and publishers. Whilst the five publications discussed above all require limited rights under their licences, three other journals and publishers, discussed below, although allowing for the retention of copyright by the author, require a far broader licence. Both the Adelaide Law Review and Griffith Law Review contracts require authors to

\footnotetext{
${ }^{78}$ See University of Queensland Law Journal, Submissions, $<$ http://www. law.uq.edu .au/uqlj-submissions>.

${ }^{79}$ See Sydney Law Review, Information for Authors (9 October 2015) < sydney.edu.au/law/ slr/guides.shtml>.

${ }^{80}$ See Queensland University of Technology Law Review, Submissions, $<$ https://lr.law.qut. edu.au /about/submissions\#authorGuidelines>.

${ }^{81}$ See Indigenous Law Centre UNSW, Policy on Publication (2012) Australian Indigenous Law Review <www.ilc.unsw.edu.au/sites/ilc.unsw.edu.au/files/AILR\%20Policy\% 20on\%20Publication \%20new.pdf $>$; University of Tasmania Law Review, Submission and Publication Agreement, University of Tasmania <www.utas.edu.au/_data/assets/pdf_file /0006/88899/Sub_Pub_Agree_UTLR1.pdf>.

${ }^{82}$ See Social Science Research Network, Frequently Asked Questions. <ssrn.com/update/ general /ssrn_faq.html\#ssrn_copyright $>$.

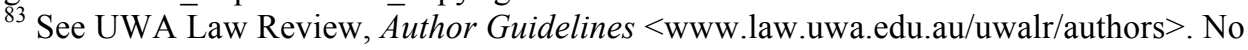
sample contract was publicly available and the scope of the licence to the publisher was unclear.
} 
agree to a 'perpetual, irrevocable, royalty free, world-wide licence'. ${ }^{84}$ While the Adelaide Law Review contract does not mention moral rights, the Griffith Law Review contract requires a broad consent to infringe authors' moral rights (except for attribution rights). It states:

The University will attribute to you authorship of the article. However, you acknowledge and agree that in giving your consent to publish, you also give consent to the University to infringe your moral rights (other than the attribution of authorship) as set out under the Copyright Act 1968 (Cth). You acknowledge and agree that the consent provided by you under this clause is a genuine consent given without duress or undue influence. ${ }^{85}$

An unidentified mainstream book publisher also allows for copyright to remain with the author, subject to a 'world-wide exclusive licence' for the term of the copyright to publish the material. ${ }^{86}$ No specific mention is made of moral rights, except to state that the author's name 'shall appear in the Work as author', thereby acknowledging the author's right of attribution. ${ }^{87}$

In relation to magazine publishers, Pacific Magazines provide for assigning 'to the Publisher all present and future rights (including copyright) subsisting in the Material anywhere in the world (including any renewals or extensions to such rights) ${ }^{88}$ In addition to this broad licence, it also requires consent to 'modify' the material and, although the provision is broad, it acknowledges that modifications should not be prejudicial to author's reputation. ${ }^{89}$

\footnotetext{
${ }^{84}$ Adelaide Law Review, Author Agreement $<$ https://www.adelaide.edu.au/press /journals/law-review/submissions/alr-author-agreement.pdf >; Griffith Law Review, Policy, Submission Requirements and Style Guide, Griffith University https://www.griffith.edu .au/criminology-law/griffith-law-review/information-for-contributors. The Griffith Law Review Agreement to Publish (2007) was the latest version available to the authors at the time of this article. In contrast to the agreement, the website instead states: "Copyright in the title and content of the Journal is vested in Griffith University" and does not allow the author to retain copyright.

${ }^{85}$ Griffith Law Review, above $\mathrm{n} 84$.

${ }^{86}$ Whilst this publisher is unidentified in this article, this type of clause has become commonly used by many commercial publishers internationally: see Cantatore, above n 50, 208.

${ }^{87}$ Ibid.

${ }^{88}$ See Writer's Contracts, Pacific Magazines: July 2010 Version <writerscontracts.com/thecontracts/pacific-publications-july-2010-version/> cl 5.

${ }^{89}$ Ibid.
} 
Fairfax publishers require authors and journalists to waive their moral rights in their work. ${ }^{90}$ Similarly, The Big Issue requires a broad consent in dealing with authors' moral rights, stating:

By submitting your material you agree that at any time we may, or we may authorise third parties to, publish, reproduce, modify and edit your material for the purpose of publication in The Big Issue (in hard copy, on our website or in any other medium) ... You consent to our use of your material in this manner even if such use would otherwise infringe your moral rights. ${ }^{91}$

In this case the consent required from the contributor is so wide as to constitute an effective waiver of the author's moral rights. These waivers imply that publishers are able to make any changes or alterations to material they deem fit, change any by-lines or titles, and omit attribution to the author. In contract law generally, waiver means the unilateral abandonment of a right or claim. Thus one party may waive a term of the contract and can no longer effectively assert that right and demand its performance. ${ }^{92}$

From a brief examination of these contracts, it is evident that there are obvious discrepancies in the ways in which copyright is treated (for example, ranging from total assignment to a variety of licences); and, specifically in the context of this article, how moral rights are treated. Significantly, in most contracts, moral rights are not specifically mentioned, and if they are, acknowledgement appears to be limited to attribution. It is also apparent that moral rights are sometimes regarded as part and parcel of copyright. Although some publishers require an outright waiver of moral rights, none of the academic journals have this requirement, apart from Griffith Law Journal that acknowledges attribution of authorship.

Finally, a brief comparison of the contract used by the Australian Society of Authors ('ASA contract') (written for authors) and an example of a standard industry publishing contract ('standard contract') — used by the unidentified mainstream book publisher mentioned above - shows significant differences in how moral rights are treated. A comparison indicates that the ASA contract includes a moral rights clause that deals with moral rights:

\section{MORAL RIGHTS}

(a) The Author asserts his/her moral rights in relation to the Work.

(b) The Publisher must identify the Author in a prominent manner by including the Author's name, or any other identification of the Author as reasonably requested by

\footnotetext{
${ }^{90}$ See Writer's Contracts, Fairfax - Analysis < writerscontracts.com/analysing-thecontracts/fairfax-analysis/ $>$. Clause 6 of the Fairfax agreement requires contributors to waive their moral rights.

${ }^{91}$ The Big Issue, Contributor Guidelines $<$ www.thebigissue.org.au/contribute> .

${ }^{92}$ McLachlan v Ryan (1987) 4 BCL 155.
} 
the Author, in a reasonably prominent position on the cover (and dust jacket where applicable), spine and internal title page, and in all appropriate publicity material.

(c) The Publisher must ensure that any permitted licensees and assignees of the Publisher:

(i) Respect the Author's moral rights in relation to the Work; and

(ii) In particular, not do or omit to do anything which would amount to a derogatory treatment of the Work ... ${ }^{93}$

The ASA contract also refers to alterations to the work, for example, specifically providing that no alterations be made to the title of the work without the author's consent. ${ }^{94}$ In contrast, the standard contract provides that, although the publisher agrees to consult with the author on the title, cover text, biographical note and cover design, the publisher reserves the right to make the final decision on all such matters. This means that the author, in signing the contract, is effectively consenting to the possible act of an involuntary title change, which may indicate a waiver of his/her moral rights.

An initial comparison of a standard Fairfax contract and a contract from the Media Entertainment and Arts Alliance ('MEAA') shows similar disparities. ${ }^{95}$ The MEAA contract protects the author's moral rights by stating: 'All copyright and other intellectual property rights in the material, including rights to publish, reproduce and communicate to the public, to subsequent publication or communication, and all other rights whatsoever belong to the contributor.' In contrast, clause 6 of the Fairfax contract states:

You waive Your moral rights (as set out in the Copyright Act 1968 (Cth)) in relation to all Fairfax Work and give Fairfax Your consent to do (or omit to do) anything that might otherwise infringe Your moral rights, such that Fairfax may reproduce and deal with all Fairfax Work free from any impediment.

However, the MEAA contract also includes the following section, which effectively equates the waiving of moral rights with economic compensation. It notes (emphasis added):

The company agrees to acknowledge contributor's moral rights in all media:

\footnotetext{
${ }^{93}$ Australian Society of Authors, ASA Contract $<$ https://www.asauthors.org /contractspapers/model-publishing-agreement-template>.

${ }^{94}$ Ibid, stating specifically: '(a) No alterations will be made to the title of the Work without the Author/Owner's consent.'

${ }^{95}$ Fairfax Standard Contributors' Agreement, Crikey $<$ blogs.crikey.com.au/contentmakers /fairfax-standard-contributors-agreement/>; The Media Entertainment and Arts Alliance, see above $\mathrm{n} 5$.
} 
(a) with a credit/byline;

(b) and agrees that it will not to be subject to derogatory treatment. If the company desires to publish or broadcast the material without a credit line, the company agrees to pay the contributor an additional fee of $100 \%$ of the fees agreed.

This doubling of payment thus confirms some of our earlier findings that conflate the economic value of copyright with moral rights and indicate that it is ultimately taken out of the hands of the creator, and placed within the discretion of the publisher or broadcaster.

\section{AnAlysis AND Conclusion}

In answering the question as to whether moral rights live up to their intended scope of preserving personality rights of authors under Australian law, and drawing from the discussion above, the answer is far from unequivocal. From the perspective of authors and journalists, the inconsistent treatment of moral rights may raise uncertainty about the value and effectiveness of the moral rights provisions in the Copyright Act. Our findings point to several key areas which are either inconsistent with authors' views, confirm their concerns, or, in cases where some respondents were unclear, shed light on the publishing environment as it pertains to moral rights. The key areas can be categorised as follows: economic nature; international contexts; author-publisher power differential; and the internet as a fundamental change agent.

Economic nature: While economic copyright and moral rights appear to represent a fundamental distinction, early case law, as found in Meskenas, and the wording of the contracts under review confirm Adeney's notion of hybridity and the principal thrust of the Ergas Committee Report. The primary object of the law in protecting the economic rights of the copyright owner, rather than the moral rights of the author, is patently illustrated in the treatment of moral rights in commercial publishing contracts such as the standard industry publishing contract and the standard Fairfax contract for freelance journalists. Whilst falling short of 'assignment' of moral rights - and thus operating within the ambits of the law - commercial publishers, through their economic power, essentially force authors and journalists to consent to extensive infringements of their moral rights. These broad forms of consent essentially amount to a waiver of moral rights, and, it could be argued, are broader than those permitted under the Act, specifically as consent provisions in relation to non-films require the consent to be 'in relation to specified acts or omissions, or specified classes or types of acts or omissions'. ${ }^{96}$ Where academic journals implement similar practices, a parallel argument can be made, the 'publish or perish' environment of academic endeavour demands that academics accept publishers' terms in order to publish their work, even if their moral rights are infringed in the process. This includes the MEAA contract that allows for non-attribution at the discretion of the publisher or broadcaster in lieu of financial compensation.

\footnotetext{
${ }^{96}$ Copyright Act s 195AWA(3)(a).
} 
International publishers: The international publishing environment is clearly a complicating factor for authors as moral rights have been inconsistently adopted and interpreted. Despite the protective provisions of Art 6bis of the Berne Convention, there are inconsistencies in the way moral rights are treated in the international context. Considering the global dissemination of works in the digital environment, it cannot be assumed that authors' moral rights will receive the same treatment in all jurisdictions. This includes some international publishers not observing the moral rights legislative provisions operating within Australia, such as Taylor \& Francis. While there remains some uncertainty when publishing within Australia, the situation is increasingly open when publishing in other jurisdictions.

Author-publisher power differential: The contracts examined indicate not only an inconsistent publishing environment for authors when publishing (in Australia and elsewhere) but a distinct lack of negotiating power. This may prevent authors from asserting their moral rights where the contract provides for waiver, or may imply a waiver by omission of moral rights and full assignment of copyright (for example, in the United States the lack of a provision for moral rights in the Copyright Act presumes a waiver of the rights). At the same time, the 'publish or perish' environment for academics and the ever-competitive environment for authors, puts them at a disadvantage. At the same time, although journalists can earn money from their publications by waiving their rights, they lose the option of asserting their moral rights. This is highlighted when comparing the ASA contract and the standard industry contract used by a mainstream publisher. In reality commercial publishers hold the power to enforce terms that favour themselves, ${ }^{97}$ as illustrated in the MEAA contract.

Internet: It has become evident that, although authors' moral rights are protected under the Copyright Act, ${ }^{98}$ the internet has widened the scope for infringement of these rights through unlawful transformation and appropriation. Authors seem unable to deal adequately with such violations. The internet's strong user-focus presents a dilemma for authors in trying to address breaches of their moral rights and copyright generally. As such, these rights remain firmly subject to economic-utilitarian considerations and a general perception that electronic material should be freely accessible in 'the new public sphere'. ${ }^{99}$ It could be argued that there is a (sometimes extreme) user-focus in electronic copyright, which leans heavily in favour of the consumer, often to the detriment of the content creator.

\footnotetext{
${ }^{97}$ For a discussion of the power balance between authors and publishers, see Francina Cantatore, 'The Power Balance Revisited: Authors, Publishers and Copyright in the Digital Sphere' (2013) 6(2) Creative Industries Journal 89.

${ }_{98}$ Copyright Act s 189.

${ }^{99}$ As suggested by Paolo Carpignano, Robin Andersen, Stanley Aronowitz and William Difazio, 'Chatter in the Age of Electronic Reproduction: Talk Television and the "Public Mind"' in Bruce Robbins (ed), The Phantom Public Sphere (University of Minnesota Press, 1993) 103.
} 
In summary, the moral rights landscape in Australia may be described as both unpredictable and somewhat unsympathetic for authors. It is evident that broad consent provisions, combined with the bargaining power of publishers, may effectively neutralise authors' moral rights. This is consistent with arguments raised during the debate period, prior to enactment in 2000. While case law provides precedents of acknowledgements of moral rights based on attribution and integrity, publishing agreements analysed for this study indicate that contracts and agreements are oriented more toward publisher rights than authors when considering the moral rights of the author. The degree of inconsistency and the limited testing of this relatively new law in Australia mean it should come as no surprise that authors are often unaware or confused about their moral rights, as indicated in this study. At the same time, it appears likely that, as this field of the law evolves, both within Australia and internationally, authors will continue to publish, either without control of their moral rights or under pressure to waive them substantially. 